Theory of Literature 
THE OPEN YALE COURSES SERIES is designed to bring the depth and breadth of a Yale education to a wide variety of readers. Based on Yale's Open Yale Courses program (http://oyc.yale.edu), these books bring outstanding lectures by Yale faculty to the curious reader, whether student or adult. Covering a wide variety of topics across disciplines in the social sciences, physical sciences, and humanities, Open Yale Courses books offer accessible introductions at affordable prices.

The production of Open Yale Courses for the Internet was made possible by a grant from the William and Flora Hewlett Foundation.

\section{RECENT TITLES}

Paul H. Fry, Theory of Literature

Shelly Kagan, Death

Dale B. Martin, New Testament History and Literature

\section{FOR THCOMING TITLES}

Christine Hayes, Introduction to the Old Testament Ian Shapiro, The Moral Foundations of Politics

Steven B. Smith, Introduction to Political Philosophy 


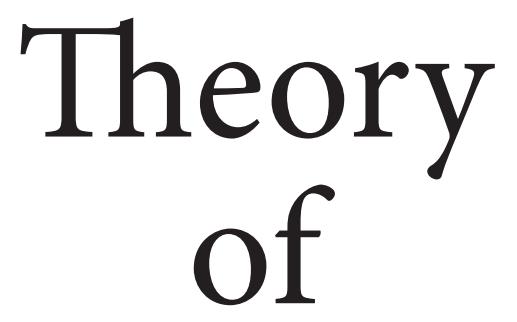

\section{Literature}

PA U L H . F R Y

Yale

UNIVERSITY PRESS

New Haven and London 


\section{Copyright (C) 2012 by Yale University.}

All rights reserved.

This book may not be reproduced, in whole or in part, including illustrations, in any form (beyond that copying permitted by Sections 107 and 108 of the U.S. Copyright Law and except by reviewers for the public press), without written permission from the publishers.

Yale University Press books may be purchased in quantity for educational, business, or promotional use. For information, please e-mail sales.press@ yale.edu (U.S. office) or sales@yaleup.co.uk (U.K. office).

Excerpts from Tony the Tow Truck by Robert Kraus, (C) 1985

by Robert Kraus, are used by permission of Grosset \& Dunlap, A Division of Penguin Young Readers Group, A Member of Penguin Group (USA) Inc., 345 Hudson Street, New York, NY 10014. All rights reserved. Hans Holbein the Younger, The Ambassadors (1533) (c) National Gallery, London / Art Resource, NY.

Set in Minion type by Westchester Book Group Printed in the United States of America

Library of Congress Cataloging-in-Publication Data

Fry, Paul H.

Theory of literature / Paul H. Fry.

p. cm. - (The open Yale courses series)

Includes bibliographical references and index.

ISBN 978-0-300-18083-1 (pbk.)

1. Literature-History and criticism-Theory, etc. 2. Semiotics.

I. Title.

$$
\begin{gathered}
\text { PN441.F79 } 2012 \\
\text { 801'.95-dc23 } 2011045263
\end{gathered}
$$

A catalogue record for this book is available from the British Library.

This paper meets the requirements of ANSI/NISO Z39.48-1992

(Permanence of Paper). 
To all my Lit 300 Teaching Fellows, with fond gratitude 
The trouble with most folks isn't so much their ignorance, it's knowin' so many things that ain't so.

-JOSH BILLINGS 